\title{
PENERAPAN BASIS AKRUAL PADA PERUSAHAAN BUMDES DALAM KEAKURATAN LAPORAN KEUANGAN (Studi Kasus pada BUMDes Dwi Amertha Sari Tahun 2017)
}

\author{
Ni Komang Dewi Sudarmiati, Ni Kadek Ayu Yusi Parwati, \\ Putu Widya Hardyanti, I Ketut Anom Ratmadi \\ Jurusan Akuntansi, Universitas Pendidikan Ganesha, Singaraja, Bali, Indonesia
}

\begin{abstract}
Abstrak
Penelitian ini bertujuan untuk mengetahui apakah basis akrual lebih baik digunakan dari basis kas pada suatu organisasi pemerintah khususnya pada BUMDes Dwi Amertha Sari, kepatuhan BUMDes Dwi Amertha Sari dalam mengikuti aturan perundang-undangan mengenai penggunaan basis akrual, dan tingkat keakuratan laporan keuangan pada BUMDes Dwi Amertha Sari dalam pencatatan menggunakan basis akrual. penggunaan akuntansi berbasis akrual lebih baik digunakan. Hasil penelitian ini yaitu pemerintah menyadari perlunya perubahan dari akuntansi berbasis kas menuju akuntansi berbasis akrual, karena pada saat ini kebanyakan perusahaan menggunakan basis akrual dan meninggalkan basis kas. Basis akrual juga memiliki beberapa kelebihan yang membuat hasil dari laporan keuangan menjadi lebih baik lagi. Khususnya di BUMDes penggunaan akuntansi berbasis akrual lebih baik digunakan daripada penggunaan akuntansi berbasis kas. Dalam laporan keuangan yang dihasilkan setiap bulan maupun tahunnya sudah bisa dikatakan akurat dikarenakan transaksi yang setiap harinya terjadi dicatat dalam laporan buku harian.
\end{abstract}

Kata kunci: Basis Akrual, Bumdes, Keakuratan, Laporan Keuangan

\begin{abstract}
This study aims to determine whether the accrual basis is better used from the cash basis of a government organization, especially in BUMDes Dwi Amertha Sari, BUMDes Dwi Amertha Sari compliance in following the laws and regulations regarding the use of accrual basis, and the level of accuracy of financial statements in BUMDes Dwi Amertha Sari in recording uses accrual basis. the use of accrual-based accounting is better used. The results of this study are that the government is aware of the need for a change from cash-based accounting to accrual-based accounting, because at present most companies use an accrual basis and leave the cash basis. The accrual basis also has several advantages that make the results of financial statements even better. Especially in BUMDes the use of accrual-based accounting is better than the use of cash-based accounting. In the financial statements that are generated every month or year it can be said to be accurate because transactions that occur every day are recorded in a daily diary report.
\end{abstract}

\section{Keywords: Accrual Basis, Bumdes, Accuracy, Financial Statements}

\section{Pendahuluan}

Laporan keuangan (Wikipedia) adalah catatan informasi keuangan suatu perusahaan pada suatu periode akuntansi yang dapat digunakan untuk menggambarkan kinerja perusahaan tersebut. Laporan keuangan adalah bagian dari proses pelaporan keuangan. Laporan keuangan yang lengkap biasanya meliputi: Neraca, Laporan laba rugi komprehensif, Laporan perubahan ekuitas, Laporan perubahan posisi keuangan yang dapat disajikan berupa laporan arus kas atau laporan arus dana, dan yang terakhir Catatan dan laporan lain serta materi penjelasan yang merupakan bagian integral dari laporan keuangan.

Menurut Standar Akuntansi Keuangan yang dikeluarkan oleh Ikatan Akuntan Indonesia tujuan laporan keuangan adalah menyediakan informasi yang menyangkut posisi 
keuangan, kinerja, serta perubahan posisi keuangan suatu perusahaan yang bermanfaat bagi sejumlah besar pemakai dalam pengambilan keputusan.

Karakteristik kualitatif merupakan ciri khas yang membuat informasi dalam laporan keuangan berguna bagi pemakai. Terdapat empat karakteristik kualitatif pokok yaitu: Dapat Dipahami, Relevan, Keandalan, dan Dapat diperbandingkan. Untuk memahami pengertian kinerja keuangan, tentu dengan memahamiterlebih dahulu apa itu kinerja. Istilah kinerja kerap dihubungkan dengan kondisi keuangan perusahaan. Kinerja dapat diartikan sebagai prestasi yang dicapai perusahaan dalam suatu periode tertentu yang mencerminkan tingkat kesehatan perusahaan tersebut (Sukhemi, 2007:23).

Kinerja merupakan gambaran prestasi yang dicapai perusahaan dalam kegiatan operasionalnya baik menyangkut aspek kuangan, aspek pemasaran, aspek penghimpunan dana dan penyaluran dana, aspek teknologi, maupun aspek sumber daya manusianya (Jumingan, 2006:239). Kinerja keuangan merupakan gambaran kondisi keuangan perusahaan pada suatu periode tertentu menyangkut aspek penghimpunan dana maupun penyaluran dana, yang biasanya diukur dengan indikator kecukupan modal, likuiditas, dan profitabilitas(Jumingan, 2006). Kinerja keuangan dapat dinilai dengan beberapa alat analisis. Berdasarkan tekniknya, analisis keuangan dapat dibedakan menjadi (Jumingan, 2006:242):

1. Analisis Perbandingan Laporan Keuangan, merupakan teknik analisis dengan cara membandingkan laporan keuangan dua periode atau lebih dengan menunjukkan perubahan, baik dalam jumlah (absolut) maupun dalam persentase (relatif).

2. Analisis Tren (tendensi posisi), merupakan teknik analisis untuk mengetahui tendensi keadaan keuangan apakah menunjukkan kenaikan atau penurunan.

3. Analisis Persentase per-Komponen (common size), merupakan teknik analisis untuk mengetahui persentase investasi pada masing-masing aktiva terhadap keseluruhan atau total aktiva maupun utang.

4. Analisis Sumber dan Penggunaan Modal Kerja, merupakan teknik analisis untuk mengetahui besarnya sumber dan penggunaan modal kerja melalui dua periode waktu yang dibandingkan.

5. Analisis Sumber dan Penggunaan Kas, merupakan teknik analisis untuk mengetahui kondisi kas disertai sebab terjadinya perubahan kas pada suatu periode waktu tertentu.

6. Analisis Rasio Keuangan, merupakan teknik analisis keuangan untuk mengetahui hubungan di antara pos tertentu dalam neraca maupun laporan laba rugi baik secara individu maupun secara simultan.

Laporan keuangan merupakan hasil akhir dari proses akuntansi. Dari laporan keuangan tersebut dapat dinilai kinerja dan perkembangan suatu organisasi. Laporan keuangan tidak hanya dibutuhkan oleh pihak internal organisasi akan tetapi ada juga pihak eksternal yang membutuhkan informasi tersebut. Karena itu harus ada standar akuntansi yang dapat dijadikan acuan dalam penyusunan laporan keuangan agar laporan keuangan yang disusun dapat dipergunakan oleh pihak-pihak berkepentingan dalam mengambil suatu keputusan.

Secara umum ada dua basis yang digunakan dalam penyelenggaraan akuntansi yaitu basis kas (cash basis) dan basis akrual (accrual basis). Pada saat ini sudah banyak para penyelenggara laporan keuangan meninggalkan basis kas dan beralih ke basis akrual. Akuntansi sektor pemerintah juga saat ini telah beralih ke basis akrual. Sesuai dengan Peraturan Pemerintah Nomor 71 Tahun 2010 tentang Standar Akuntansi Pemerintahan pada Pasal 4 Ayat (1) yang bunyinya adalah Pemerintah menerapkan SAP Berbasis Akrual. 
Badan usaha milik desa merupakan usaha desa yang dikelola oleh Pemerintah Desa, dan berbadan hukum. Pemerintah Desa dapat mendirikan Badan Usaha Milik Desa sesuai dengan kebutuhan dan potensi Desa. Pembentukan Badan Usaha Milik Desa ditetapkan dengan Peraturan Desa.

Sebagai salah satu lembaga ekonomi yang beroperasi dipedesaan, BUMDes harus memiliki perbedaaan dengan lembaga ekonomi pada umumnya. Hal ini agar keberadaaan dan kinerja BUMdes Mampu memberikan kontribusi yang signifikan terhadap peningkatan kesejahteraan warga desa. BUMDes juga diwajibkan untuk melakukan pelaporan keuangan. Sebagai salah satu organisasi pemerintahan BUMDes harus juga mengikuti peraturan perundangundangan yang ada. Karena BUMDes merupakan badan usaha yang dimiliki oleh pemerintah maka sudah seharusnya BUMDes menerapkan Basis Akrual dalam pencatatan keuangannya. Keakuratan dari penggunaan Basis akuntansi yang digunakan sangat penting bagi suatu laporan keuangan. Informasi akuntansi yang dihasilkan haruslah akurat.

Berdasarkan masalah diatas, adapun rumusan masalah yang dilakukan antara lain Apakah basis akrual lebih baik digunakan dari basis kas pada suatu organisasi pemerintah khususnya pada BUMDes Dwi Amertha Sari, Bagaimana kepatuhan BUMDes Dwi Amertha Sari dalam mengikuti aturan perundang-undangan mengenai penggunaan basis akrual, serta Bagaimana tingkat keakuratan laporan keuangan pada BUMDes Dwi Amertha Sari dalam pencatatan menggunakan basis akrual

\section{Hasil dan Pembahasan}

\subsection{Penggunaan Akuntansi Berbasis Akrual Pada Suatu Organisasi Pemerintah Khususnya Pada BUMDes Dwi Amertha Sari}

Basis kas merupakan basis akuntansi yang pertama kali digunakan dalam penyusunan laporan keuangan pemerintah. Basis kas masih banyak digunakan dalam pemerintahan. PP Nomor 71 Tahun 2010 disebutkan bahwa, "Basis kas adalah basis akuntansi yang mengakui pengaruh transaksi dan peristiwa lainnya pada saat kas atau setara kas diterima atau dibayar". Ciri utama dari basis kas ini adalah pendapatan baru akan diakui pada saat kas diterima, dan bukan pada saat hak atas pendapatan tersebut timbul. Sama halnya dengan pengakuan beban, seperti belanja juga baru akan diakui jika belanja tersebut telah dibayarkan dan bukan pada saat kewajiban untuk membayar timbul. Sistem penacatatan menggunakan akuntansi berbasis kas sangat sederhana.

Menurut Peraturan Pemerintah RI Nomor 71 Tahun 2010 tentang Standar Akuntansi Pemerintah Pasal 4 Ayat (1) dinyatakan bahwa Pemerintah menerapkan SAP Berbasis Akrual. Basis akuntansi akrual, seperti yang disimpulkan oleh KSAP (2006:3), adalah suatu basis akuntansi di mana transaksi ekonomi dan peristiwa lainnya diakui, dicatat, dan disajikan dalam laporan keuangan pada saat terjadinya transaksi tersebut, tanpa memerhatikan waktu kas atau setara kas diterima atau dibayarkan. Basis akrual pada saat ini merupakan basis yang umum digunakan oleh semua organisasi, baik organisasi pemerintah maupun organisasi swasta seperti perusahaan-perusahaan. Disaat pemerintah mengeluarkan peraturan mengenai perubahan penggunaan basis akuntansi dari basis kas menuju akrual, pemerintah pasti sudah mempertimbangkan hal-hal yang berkaitan dengan laporan keuangan yang disusun. Sangat tidak mungkin jika pemerintah melakukan perubahan untuk tujuan yang buruk. Setiap perubahan yang dilakukan pasti bertujuan untuk menjadi lebih baik lagi. Maka dari itu pastinya basis akrual mempunyai kelebihan dari pada basis kas yang membuat pemerintah mengeluarkan peraturan tersebut. 
Perubahan yang dilakukan memerlukan waktu untuk penyesuaiannya dalam lingkungan penggunaan. Saat ini pemerintah tidak memaksakan semua organisasi pemerintah untuk menggunakan basis akrual, tapi disarankan untuk menggunakan basis akrual. Masih ada organisasi pemerintah yang menggunakan basis kas dan ada juga yang bertahap dalam menghadapi perubahan ini, dan basis ini disebut basis kas menuju akrual. Akuntansi berbasi akrual ini selain mencatat pengeluaran dan penerimaan kas, juga mencatat adanya hutang dan piutang dari suatu organisasi. Oleh karena itu akuntansi berbasis akrual memberikan gambaran yang sangat jelas atas kondisi keuangan organisasi daripada akuntansi berbasis kas. Akan tetapi akuntansi berbasis akrual mempunyai sistem yang lebih kompleks dari pada akuntansi berbasis kas.

Basis akrual ini mempunyai kelebihan dibandingkan dengan basis kas yaitu:

1. Basis akrual bisa mencerminkan besarnya kas yang tersedia tidak seperti basis kas yang tidak bisa mencerminkan besarnya kas yang tersedia karena basis kas hanya akan mengakui adanya transaksi saat kas atau setara kas diterima atau dibayar.

2. Dalam basis akrual piutang yang tidak tertagih tidak akan dihapus secara langsung tetapi akan dihitung kedalam estimasi piutang tak tertagih sedangkan dalam basis kas penghapusan piutang dilakukan secara langsung dan tidak adanya estimasi piutang tak tertagih.

3. Dalam basis akrual adanya peningkatan pendapatan karena kas yang belum diterima dapat diakui sebagai pendapatan, beda halnya dalam basis kas yang hanya bisa mengakui pendapatan saat kas sudah diterima.

4. Dalam basis kas setiap pengeluaran kas diakui sebagai beban, tetapi dibasis akrual tidak semua diakui sebagai beban melainkan dicatat kedalam masing-masing akun sesuai dengan transaksi yang terjadi.

5. Dalam basis kas manajemen sulit menetukan suatu kebijakan kedepannya karena selalu berpatokan kepada kas, tetapi dalam basis akrual banyak hal yang dapat dijadikan patokan dalam mengambil keputusan kebijakan kedepannya.

Di dalam basis akrual juga memiliki kekurangan dalam penerapannya yaitu:

1. Harus menyiapkan biaya yang cukup besar untuk menangani hal-halsebagai berikut:

a. Biaya untuk penilaian aset

b. Biaya untuk penyiapan kebijakan akuntansi

c. Biaya untuk membangun sistem akuntansi termasuk membeli komputer atau peralatan lainnya untuk mendukung sistem tersebut

d. Biaya untuk menyiapkan sumber daya manusia yang memadai dan mumpuni untuk menangani akuntansi pemerintahan berbasis akrual

2. Basis akrual pada dasarnya didesain untuk mengukur laba sehingga kurang memberikan arti pada sektor publik atau pemerintahan. Karena ada dasarnya tujuan dari pemerintah adalah melayani rakyat agar tercapainya kesejahteraan sosial, jadi akuntansi pemerintah tidak mementingkan laba yang akan di dapat, pemerintah hanya memikirkan bagaimana dalam merealisasikan anggaran agar tidak terjadi defisit agar negara tidak merugi.

3. Memerlukan ruang yang lebih luas dalam hal pertimbangan profesional(profetional judgement) baik oleh penyedia laporan keuangan (entitas laporan keuangan/entitas akuntansi) maupun auditor pemerintahan.

Di dalam BUMDes Dwi Amertha Sari, pencatatan keuangan disana sudah menggunakan basis akrual. BUMDes Dwi Amertha Sari sudah menerapkan basis akrual 
karena selain mengikuti peraturan yang telah dibuat, pihak dari BUMDes Dwi Amertha Sari juga melihat kelebihan dari penggunaan basis akrual ini. Penggunaan basis akrual ini lebih baik digunakan ketimbang penggunaan basis kas. Banyaknya pos-pos yang ada dalam pencatatan laporan keuangan di BUMDes Dwi Amertha Sari memungkinkan pihak manajemen bisa membuat keputusan dengan gampang karena memiliki banyak dasar yang dapat dijadikan acuan dalam membuat kebijakan tersebut. Dalam BUMDes Dwi Amertha Sari, pihak keuangan mencatat beban-beban yang belum terjadi pada awal periode, hal tersebut akan menggambarkan kondisi organisasi yang sebenarnya dan juga dengan mencatat pengakuan beban diawal akan memungkinkan pihak organisasi mengetahui resiko yang mungkin terjadi di dalam suatu pengelolaan organisasi dan agar dapat di antisipasi agar masalah tersebut tidak membuat organisasi itu kinerjanya menurun. Karena penyebab pemerintah menerapkan basis akrual ini ke dalam akuntansi pemerintahan adalah dengan harapan mampu memperbaiki kinerja pemerintahan secara keseluruhan, baik dalam hal penyusunan anggaran maupun realisasi anggaran. Hasil dari pencatatan keuangan di BUMDes Dwi Amertha Sari akan menghasilkan sebuah laporan yang memiliki tujuan adalah sebagai berikut:

1. Untuk mengetahui perkembangan usaha dari waktu ke waktu, baik itu informasi tentang perkembangan penjualan, struktur permodalan sampai dengan informasi tentang laba atau rugi yang dihadapi BUMDes Dwi Amertha Sari tersebut.

2. Untuk mengetahui prospek usaha kedepannya, apakah akan merugi atau sebaliknya, jika usaha tersebut diprediksikan akan merugi maka manajemen bisa mengantisipasi kerugian itu jika diketahui di awal dan bisa menghindar dari kerugian tersebut.

3. Untuk mengetahui bagaimana penggunaan sumber dana pada BUMDes Dwi Amertha Sari, sehingga nantinya BUMDes Dwi Amertha Sari bisa mengevaluasi kinerja keuangan pada BUMDes Dwi Amertha Sari.

4. Karena BUMDes Dwi Amertha Sari salah satu usahanya bergerak dalam usaha dagang, laporan keuangan ini diperlukan untuk mengetahui kondisi persediaan barang setiap saat. Sehingga jika sudah mengetahui kondisi perusahaan maka dapat digunakan untuk menyusun strategi manajemen persediaan.

Basis akrual juga mendukung penggunaan anggaran sebagai teknik pengendalian. Karena pada basis kas, pembayaran hanya direkam jika hal itu telah dilakukan, sementara pembayaran kewajiban dapat dilakukan dengan jarak waktu tertentu setelah timbulnya kewajiban itu sendiri. Untukalasan penganggaran, BUMDes Dwi Amertha Sari dapat lebih baik menggunakan akuntansi berbasis akrual. Dan untuk alasan yang lain BUMDes Dwi Amertha Sari lebih baik dalam menggunakan akuntansi berbasi akrual karena akuntansi berbasi akrual memiliki kelebihan yang sangat banyak.

\subsection{Kepatuhan BUMDes Dwi Amertha Sari Dalam Mengikuti Aturan Perundang- Undangan Mengenai Penggunaan Basis Akrual}

Badan usaha milik desa yang sering disebut dengan BUMDes adalah sebuah lembaga usaha desa yang dikelolah oleh pemerintah desa juga masyarakat desa tersebut dengan tujuan untuk memperkuat perekonomian desa dan dibentuk berdasarkan kebutuhan dan potensi yang ada di desa tersebut. BUMDes merupakan sebuah badan usaha yang mampu membantu masyarakat dalam segala hal antara lain memenuhi kebutuhan seharihari, menjadi peluang usaha atau lapangan pekerjaan, menambah wawasan masyarakat desa. Tujuan dari pendirian Badan Usaha Milik Desa menurut Peraturan Menteri Desa,Pembangunan Daerah Tertinggal, dan Transmigrasi Republik Indonesia NO. 4 Tahun 
2015 Tentang Pendirian, Pengurusan dan Pengelolaan, dan Pembubaran Badan Usaha Milik Desa Bagian Kedua yang membahas tentang Pendirian BUMDes, Pasal 2 menyatakan bahwa "Pendirian BUM Desa dimaksudkan sebagai upaya menampung seluruh kegiatan di bidang ekonomi dan/atau pelayanan umum yang dikelola oleh Desa dan/atau kerja sama antar-Desa." Adapun dalam Pasal 3 menyatakan bahwa "Pendirian BUM Desa bertujuan: a. meningkatkan perekonomian Desa; b. mengoptimalkan aset Desa agar bermanfaat untuk kesejahteraan Desa; c. meningkatkan usaha masyarakat dalam pengelolaan potensi ekonomi Desa; d. mengembangkan rencana kerja sama usaha antar desa dan/atau dengan pihak ketiga; e. menciptakan peluang dan jaringan pasar yang mendukung kebutuhan layanan umum warga; f. membuka lapangan kerja; g. meningkatkan kesejahteraan masyarakat melalui perbaikan pelayanan umum, pertumbuhan dan pemerataan ekonomi Desa; dan h. meningkatkan pendapatan masyarakat Desa dan Pendapatan Asli Desa." Adapun ciri-ciri dari BUMDes, antara lain :

1) Kekuasaan penuh di tangan desa, dan dikelola bersama masyarakat desa

2) Modal bersama yakni bersumber dari desa sebesar $51 \%$ dan dari masyarakat $49 \%$, dilakukan dengan cara penyerataan modal (saham atau andil).

3) Menggunakan falsafah bisnis yang berakar dari budaya lokal untuk melakukan kegiatan operasional. Proses operasionalisasi ini di kontrol bersama oleh BPD,Pemerintah Desa dan anggota masyarakat. Untuk bidang yang dipilih bagi badan usaha desa disesuaikan dengan potensi dan informasi pasar.

4) Keuntungan yang diperoleh dari produksi dan penjualan ditujukan untuk meningkatkan kesejahteraan anggota dan masyarakat desa melalui kebijkan desa.

5) Pemberian fasilitas dan pengawasan dilakukan oleh Pemerintah Provinsi,Pemerintah Kabupaten, dan Pemrintah Desa.

Itulah ciri-ciri yang dimiliki oleh BUMDes. Perlu diketahui bahwasanya BUMDes memiliki empat tujuan utama yakni :

a. Meningkatkan perekonomian masyarakat desa

b. Meningkatkan pendapatan masyarakat desa

c. Mengoptimalkan potensi sumber daya alam untuk kebutuhan masyarakat

d. Menjadi alat pemerataan dan pertumbuhan ekonomi desa.

Pada dasarnya pendirian dan pengelolaan BUMDes adalah sebuah wujud dari pengelolahan ekonomi produktif desa yang dilakukan secara kooperatif, partisipatif, emansipatif, transparansi, akuntabel dan sustainable. Untuk itulah membutuhkan pengelolahan BUMDes yang serius agar bisa berjalan secara mandiri, efektif dan professional.

Untuk mencapai tujuannya BUMDes menggunakan cara pemenuhankebutuhan masyarakat dalam bentuk pelayanan barang dan jasa. Kebutuhan masyarakat yang harus dipenuhi adalah kebutuhan pokok. Selain itu pembekalan usaha bagi masyarakat juga menjadi salah satu tanggungjawab dari BUMDes. BUMDes memiliki beberapa landasan hukum yang menjadi dasar dan acuan dalam segala aktivitasnya. Pendirian BUMDes dilandasi oleh Undang-Undang no 32 tahun 2004 tentang Pemerintahan Daerah dan PP no 72 tahun 2005 tentang Desa.

Salah satu BUMDes yang berdiri di kabupaten Buleleng yaitu BUMDes Dwi Amertha Sari yang bertempat di Desa Jineng Dalem Kabupaten Buleleng. BUMDes ini berdiri sejak 23 Oktober 2014, BUMDes ini adalal salah satu program Sadu Bali Mandhara (SBM) yang dibuat oleh bapak I Made Mangku Pastika selaku Gubernur Provinsi Bali pada saat itu, 
program ini dinamakan "Program Sadu". Dana awal yang diberikan untuk membangun BUMDes ini adalah Rp. 1.020.000.000. Peraturan Menteri Desa, Pembangunan Daerah Tertinggal, dan Transmigrasi Republik Indonesia NO. 4 Tahun 2015 Tentang Pendirian, Pengurusan dan Pengelolaan, dan Pembubaran Badan Usaha Milik Desa Bagian Ketiga yang membahas tentang Modal BUMDes, Pasal 19 ayat (2) menyatakan bahwa "Unit usaha dalam BUM Desa sebagaimana dimaksud pada ayat (1) dapat memanfaatkan sumber daya lokal dan teknologi tepat guna, meliputi: a. air minum Desa; b. usaha listrik Desa; c. lumbung pangan; dan d. sumber daya lokal dan teknologi tepat guna lainnya ". Sejak didirikannya BUMDes di Desa Jineng Dalem ini banyak kontribusi yang telah dilakukan untuk masyarakat yaitu dengan melakukan berbagai jenis usaha yang sesuai dengan aturan yang tertera diatas yaitu diantaranya melayani fotokopi, menjual sembako, menjual ATK, dan melakukan permodalan yang secara langsung terjun ke masyarakat, selain untuk modal BUMDes tersebut juga untuk melatih masyakat dalam bidang pertanian, perdagangan, berbagai kerajinan, dan peternakan.

Sesuai dengan Peraturan Menteri Desa, Pembangunan Daerah Tertinggal, dan Transmigrasi Republik Indonesia NO. 4 Tahun 2015 Tentang Pendirian, Pengurusan dan Pengelolaan, dan Pembubaran Badan Usaha Milik Desa Bagian Ketiga yang membahas tentang Modal BUMDes, Pasal 17 (1) Modal awal BUM Desa bersumber dari APB Desa. (2) Modal BUM Desa terdiri atas: a. penyertaan modal Desa; dan b. penyertaan modal masyarakat Desa. Modal yang didapat oleh BUMDes hingga saat ini berasal dari desa dan keuntungan dari jenis usaha yang dilakukan, adapun $45 \%$ keuntungan dari usaha menjadi modal untuk BUMDes dalam menganggarkan segala jenis usahanya.

Sejalan dengan UU 23 Tahun 2014 mengenai otonomi daerah, maka terbitlah UU No. 6 Tahun 2014 tentang desa sebagai muara dari asas desentralisasi itu sendiri yang didalamnya diatur tentang pengelolaan keuangan desa (Pasal 72). Dengan adanya undangundang tersebut maka desa berkewajiban untuk menyelenggarakan akuntansi untuk mendukung proses akuntanbilitas dantransparasi kepada publik. Pencatatan akuntansi yang sesuai dengan Standar Akuntansi Pemerintahan (SAP) yang seharusnya digunakan dalam BUMDes adalah basis akrual sesuai dengan Permendagri Nomor 64 Tahun 2013 mengenai kebijakan akuntansi desa dalam penyajian laporan keuangan dan entitas pelaporan dan juga PP Nomor 71 tahun 2010 yang memuat standar akuntansi pemerintah berbasis akrual. Dalam BUMDes Dwi Amertha Sari ini pun sudah menerapkan pencatatan laporan keuangan dengan menggunakan basis akrual. " Disini kami sudah mencatat transaksi sesuai dengan peraturan yang ada, yaitu dengan basis akrual untuk mengetahui informasi operasi atau kegiatan sesuai dengan peraturan." Ungkap Hendri Ari Susila selaku Ketua BUMDes Dwi Amertha Sari. Jadi dapat disimpulkan bahwa dalam hal modal yang didapatkan, jenis usaha yang dilaksanakan, serta metode pencatatan yang dilakukan oleh BUMDes Dwi Amertha Sari sudah sesuai dengan peraturan yang berlaku.

\subsection{Tingkat keakuratan laporan keuangan pada BUMDes Dwi Amertha Sari dalam pencatatan menggunakan basis akrual}

Laporan keuangan adalah untuk menyediakan informasi keuangan mengenai suatu badan usaha yang akan dipergunakan oleh pihak-pihak yang berkepentingan sebagai bahan pertimbangan didalam pengambilan-pengambilan keputusan ekonomi. Laporan keuangan bagi pihak manajemen berfungsi sebagai laporan pertanggungjawaban keuangan pada pemilik modal. Bagi pemilik modal laporan keuangan berfungsi untuk mengevaluasi kinerja manajer perusahaan selama satu periode. 
Menurut (Martono dan Murjinto, 2008:55) menyatakan bahwa laporan keuangan adalah ikthisar mengenai keadaan keuangan suatu perusahaan pada suatu saat tertentu. Laporan secara garis besar dibedakan menjadi empat macam yaitu laporan neraca, laporan laba rugi, laporan arus kas, dan laporan perubahan modal.

Laporan keuangan memuat informasi yang bersifat keuangan seperti jumlah aktiva, jumlah kewajiban, jumlah pendapatan,jumlah modal, jumlah biaya dan arus kas. Informasi yang bersifat keuangan diambil dari ringkasan transaksi yang terjadi selama satu periode. Menurut (Harahap, 2005:66) menyatakan bahwa tujuan laporan keuangan adalah menyediakan informasi yang menyangkut laporan posisi keuangan, kinerja serta perubahan posisi keuangan suatu perusahaan yang bermanfaat bagi sejumlah besar pemakai dan pengembalian keputusan ekonomi. Laporan keuangan juga memiliki tujuan dan dapat dikelompokan menjadi 2 yaitu :

1. Tujuan Khusus yaitu menyajikan laporan posisi keuangan, hasil usaha dan perubahan posisi keuangan lainnya secara wajar dan sesuai GAAP, memperkirakan prospek arus kas, memahami kondisi keuangan perusahaan, memahami kinerja perusahaan, dan memahami bagaimana kas diperoleh dan digunakan.

2. Tujuan Umum yaitu memberikan informasi yang terpercaya mengenaisumber-sumber ekonomi dan kewajiban perusahaan serta memberikan informasi menganai sumber kekayaan bersih yang berasal dari kegiatan usaha dalam mencari laba.

Untuk memenuhi tujuan yang menyediakan informasi berorientasi pengguna, laporan keuangan harus memiliki karakteristik kualitatif yang memadai. Karakteristik kualitatif merupakan ciri khas yang membuat informasi berguna bagi pemakai

1. Dapat dipahami

Informasi yang berkualitas adalah informasi yang dengan mudah dansegera dapat dipahami oleh pemakainya. Pemakai informasi diasumsikan mempunyai pengetahuan yang memadai mengenai aktivitas ekonomi danbisnis, akuntansi serta kemauan untuk mempelajari informasi dengan ketekunan yang wajar

2. Relevan

Informasi mempunyai kualitas relevan bila dapat mempengaruhi keputusan ekonomi pemakai, yaitu dengan cara dapat berguna untuk mengevaluasi peristiwa masalalu. Relevansi informasi bermanfaat dalam peramalan dan penegasan yang keduanya berkaitan satu dengan yang lainnya

3. Keandalan

Informasi memiliki kualitas yang andal apabila bebas dari pengertianyang menyesatkan, kesalahan material, dan dapat diandalkan keandalan ini penting dan dapat mempengaruhi relevansi karena jika hakikat dan penyajiannya tidak dapat diandalkan maka penggunaan informasi tersebut secara potensial dapat menyesatkan.

Menurut (IAI, 2012) menyatakan integritas laporan keuangan dapat dicapai apabila laporan keuangan memenuhi karakteristik keandalan (realbility), dan sesuai dengan prinsip akuntansi yang berlaku umum. Reability memiliki kualitas sebagai berikut :

1. Daya Uji (Verifiability)

Laporan keuangan suatu entitas yang mempunyai kondisi yang sama dengan laporan keuangan entitas lainnya akan mendapat opini yang sama jika diaudit oleh auditor yang berbeda

2. Ketepatan Penyajian (Representational faithfulness) 
Angka dan keterangan yang disajikan sesuai dengan apa yang ada dan benar-benar terjadi

3. Netralitas (Neutrality)

Informasi dari laporan keuangan harus diarahkan pada kebutuhan umum pemakai, dan tidak tergantung pada kebutuhan dan keinginan pihak tertentu. Tidak boleh ada usaha untuk menyajikan informasi yang menguntungkan beberapa pihak, sementara hal tersebut akan merugikan pihak lainyang memiliki kepentingan yang berlawanan.

Menurut (Keiso, Weygandt dan Warfield, 2011) menjelaskan informasi dan laporan keuangan dikatakan benar dan jujur apabila sesuai dengan karakteristik faithful representation, yang memiliki 3 karalteristik yaitu completeness, neutrality, dan free from error. Akan tetapi, faitful representation tidak berarti terbebas dari kesalahan secara keseluruhan. Dari penjelasan mengenai laporan keuangan terdapat keterkaitan tentang penggunaan basis akrual tidak hanya untuk penyusunan sebuah laporan keuangan, akan tetapi dibeberapa negara telah menggunakan basis akrual baik itu untuk menyusun laporan keuangan maupun digunakan untuk penganggaran.

Dinegra-negara anggota OECD, sejauh ini basis akrual itu sendiri lebih banyak diterima untuk laporan keuangan daripada tujuann penganggaran. Penggunaan basis akrual untuk pelaporan keuangan bisa saja diimplementasikan dalam hubungannya dengan anggaran berbasis kas ataupun dengan sistem lainnya. Namun sejumlah pemerintah (jurisdiksi) yang menggunakan sistem ganda (dual system) tersebut menemukan rintangan berupa resistensi penerimaan akuntansi berbasis akrual. Dengan digunakannya sistem ganda tersebut maka diperlukan adanya rekonsiliasi yang ekstensif diantara dua sistem tersebut. Keberhasilan akuntansi akrual tersebut sebagian tergantung dari ekstensif yang diberikan oleh para manajer, dengan cara tersebut maka hasil dari laporan keuangan yang diinginkan dapat mencapai target yang maksimal.

Pengunaan basis akrual itu sendiri yang menjadi tren diberbagai negarasaat ini tentu saja sangat terkait dengan tujuan dan manfaat dari penggunaan itu sendiri.penggunaan basis akrual merupakan salah satu cirri praktik manajemen keuangan modern (sektor publik) yang bertujuan untuk memberikan informasi yang lebih transparan mengenai biaya pemerintah dan meningkatkan kualitas pengambilan keputusan didalam pemerintah dengan menggunakan informasi yang diperluas. Karena itu hanya basis akrual yang hanya mengakui semua biaya-biaya dengan demikian dapat mendukung pengembalian keputusan oleh para manajer secara efektif dan efisien. Hal tersebut juga diterapkan pada setiap laporan keuangan khususnya laporan keuangan usaha yang ada didaerah atau di desa seperti BUMDes.

Dari data yang diperoleh melalui observasi di BUMDes Dwi Amertha Sari, bahwa semua biaya-biaya diakui dan transaksi-transaksi yang terjadi setiap harinya dicatat oleh pihak bendahara melalui 3 tahapan yaitu transaksi harian, transaksi bulanan, dan transaksi tahunan. Dengan pembahasan yang sudah dijelaskan diatas maka dapat dikatakan bahwa BUMDes Dwi Amertha Sari menggunakan atau menerapkan basis akuntansi akrual dan laporan keuangan yang dibuat setiap hari, bulan, dan tahun sudah dikatakan akurat.

Di BUMDes Dwi Amertha Sari Akuntansi berbasis akrual selain mencatat transaksi pengeluaran dan penerimaan kas, juga mencatat jumlah hutang dan piutang organisasi. Oleh karena itu, akuntansi berbasis akrual memberikan gambaran yang lebih akurat atas kondisi keuangan organisasi daripada akuntansi berbasis kas. Namun, jelas bahwa catatan menggunakan basis akrual lebih kompleks daripada basis kas. Lebih jauh lagi, basis akrual 
mendukung penggunaan anggaran sebagai teknik pengendalian. Karena pada basis kas, pembayaran hanya direkam jika hal itu telah dilakukan, sementara pembayaran kewajiban dapat dilakukan dengan jarak waktu tertentu setelah timbulnya kewajiban itu sendiri. Untuk alasan penganggaran, organisasi dapat lebih baik menggunakan akuntansi berbasis akrual. Untuk mengadopsi akuntansi basis akrual, BUMDes Dwi Amertha Sari memerlukan informasi seperti pendapatan atas investasi yang belum jatuh tempo.

Organisasi juga akan memerlukan informasi mengenai kewajiban keuangan masa depan yang dapat diperkirakan jumlahnya. Dengan komputerisasi sistem akuntansi, upaya yang diperlukan untuk menjaga informasi ini dapat dilakukan secara memadai. Penerapan Akuntansi Basis Akrual BUMDes Dwi Amertha Sari Akuntansi penting karena Dalam rangka mengemban amanat Undang-Undang Nomor 1 Tahun 2004 yang menetapkan basis akrual diterapkan selambat-lambatnya pada tahun anggaran 2008, KSAP sejak tahun 2006 telah memulai mengkaji, melakukan penelitian dan pembahasan serta menyiapkan Draft Standar Akuntansi Pemerintahan yang berbasis akrual berdasarkan kesepakatan sementara dari KSAP. Penyusunan Draft SAP yang berbasis akrual tersebut dilakukan secara hatihati dengan mempertimbangkan antara lain:

1. SAP berbasis kas menuju akrual (PP Nomor 24 Tahun 2005 - cash towards accrual) baru saja diterbitkan dan belum sepenuhnya diimplementasikan oleh pemerintah pusat maupun pemerintah daerah.

2. SAP berbasis akrual yang akan disusun sesuai Undang-undang Keuangan Negara mengharuskan perubahan/penyempurnaan pada bidang perencanaan dan penganggaran, dimana KSAP tidak dalam posisi untuk membuat ketentuan/peraturan di bidang tersebut (misalnya keharusan untuk menganggarkan terhadap kewajibankewajiban yang harus dibayar pada akhir tahun buku).

Penyusunan SAP berbasis akrual dapat dilakukan dengan 2 cara, yaitu:

(1) menyusun PSAP berbasis akrual seluruhnya dari awal; dan

(2) menyesuaikan PSAP berbasis kas menuju akrual (sesuai PP Nomor 24 Tahun 2005) menjadi PSAP berbasis akrual dengan referensi IPSAS, dengan mempertimbangkan praktik-praktik yang berlaku, administrasi pemerintahan yang ada dan kemampuan sumber daya manusia. Atas dua strategi tersebut, KSAP sepakat menggunakan strategi yang ke-2, dengan pertimbangan sebagai berikut:

a. SAP berbasis kas menuju akrual telah disusun dengan mengacu pada beberapa referensi bertaraf internasional antara lain IPSAS, Governmental Accounting Standards Board (GASB), dan Government Finance Statistics (GFS), sehingga diharapkan SAP berbasis kas menuju akrual yang akan disesuaikan menjadi akrual sudah dapat diterima umum.

b. Mengurangi resistensi dari para pengguna SAP (PP Nomor 24 Tahun 2005) terhadap perubahan basis akuntansi. Pengguna PP Nomor 24 Tahun 2005 masih dalam tahap pembelajaran dan perlu waktu yang cukup lama untuk memahaminya sehingga apabila SAP akrual berbeda jauh dengan SAP berbasis kas menuju akrual akan menimbulkan resistensi;

c. Penyusunan SAP berbasis akrual relatif menjadi lebih mudah karena sebagian dari PSAP berbasis kas menuju akrual (PSAP Nomor 01, 05, 06, 07, dan 08 dalam PP $24 / 2005)$ telah berbasis akrual sehingga hanya memerlukan penyesuaian beberapa PSAP berbasis akrual; 
d. Penerapan SAP berbasis akrual yang disusun sesuai pola SAP berbasis kas menuju akrual lebih mudah bagi para pengguna standar karena sudah disosialisasikan, dan para pengguna telah memiliki pemahaman dan pengalaman terhadap SAP berbasis kas menuju akrual.

e. Perkembangan terakhir, telah terbit Peraturan Pemerintah Nomor 71 tahun 2010 tentang SAP berbasis Akrual sebagai pengganti PP 24 tahun 2005. Kronologis terbitnya PP No. 71 tahun 2010 disajikan pada Lampiran I.

Jika dibandingkan dengan akuntansi pemerintah berbasis kas menuju akrual, akuntansi berbasis akrual sebenarnya tidak banyak berbeda. Pengaruh perlakuan akrual dalam akuntansi berbasis kas menuju akrual sudah banyak diakomodasi di dalam laporan keuangan terutama neraca yang disusun sesuai dengan Peraturan Pemerintah (PP) Nomor 24 Tahun 2005 tentang Standar Akuntansi Pemerintahan (SAP). Keberadaan pos piutang, aset tetap, hutang merupakan bukti adanya proses pembukuan yang dipengaruhi oleh asas akrual.

Ketika akrual hendak dilakukan sepenuhnya untuk menggambarkan berlangsungnya esensi transaksi atau kejadian, maka kelebihan yang diperoleh dari penerapan akrual adalah tergambarkannya informasi operasi atau kegiatan. Dalam sektor komersial, gambaran perkembangan operasi atau kegiatan ini dituangkan dalam Laporan Laba Rugi. Sedangkan dalam akuntansi pemerintah, laporan sejenis ini diciptakan dalam bentuk Laporan Operasional atau Laporan Surplus/Defisit.

Dengan demikian, perbedaan kongkrit yang paling memerlukan perhatian adalah jenis/komponen laporan keuangan. Perbedaan mendasar SAP PP 24/2005 dengan SAP Akrual terletak pada PSAP 12 mengenai Laporan Operasional. Entitas pemerintah melaporkan secara transparan besarnya sumber daya ekonomi yang didapatkan, dan besarnya beban yang ditanggung untuk menjalankan kegiatan pemerintahan. Surplus/defisit operasional merupakan penambah atau pengurang ekuitas/kekayaan bersih entitas pemerintahan bersangkutan. Secara ringkas perbedaan komponen laporan keuangan basis akrual dengan basis kas menuju akrual disajikan pada Lampiran II.

Walaupun basis akrual berlaku efektif untuk laporan keuangan atas pertanggungjawaban pelaksanaan anggaran mulai tahun 2010, tetapi apabila entitas pelaporan belum dapat menerapkan PSAP ini, entitas pelaporan dapat menerapkan PSAP Berbasis Kas Menuju Akrual paling lama 4 (empat) tahun setelah Tahun Anggaran 2010.

Penerapan SAP Berbasis Akrual Akuntansi Di BUMDes Dwi Amertha Sari dapat dilaksanakan secara bertahap dari penerapan SAP Berbasis Kas Menuju Akrual menjadi penerapan SAP Berbasis Akrual. Ketentuan lebih lanjut mengenai penerapan SAP Berbasis Akrual secara bertahap pada pemerintah pusat diatur dengan Peraturan Menteri Keuangan, sedangkan untuk pada pemerintah daerahdiatur dengan Peraturan Menteri Dalam Negeri (pasal 7 PP 71 tahun 2010). Untuk pemerintah pusat, strategi penerapan basis akrual, sudah dilakukan mulai tahun 2009, yaitu dengan menyajikan informasi akrual untuk pendapatan dan belanja sebagai pelengkap LRA berbasis kas. Contoh strategi atau pentahapan penerapan basis akrual yang dapat dilakukan baik oleh pemerintah pusat dan pemerintah daerah dapat dilihat pada Lampiran III dan IV.

Tantangan Akuntansi Berbasis Akrual Keberhasilan perubahan akuntansi pemerintahan sehingga dapat menghasilkan laporan keuangan yang lebih transparan dan lebih akuntabel memerlukan upaya dan kerja sama dari berbagai pihak. Jika penerapan akuntansi berbasis kas menuju akrual saja masih banyak menghadapi hambatan, lebih-lebih 
lagi jika pemerintah akan menerapkan akuntansi berbasis akrual. Beberapa tantangan dalam implementasi akuntansi pemerintahan berbasis akrual adalah:

1. Sistem Akuntansi dan IT Based System

Melihat kompleksitas implementasi akuntansi berbasis akrual, dapat dipastikan bahwa penerapan akuntansi berbasis akrual di lingkungan pemerintahan memerlukan sistem akuntansi dan IT based system yang lebih rumit. Selain itu perlu juga dibangun sistem pengendalian intern yang memadai untuk memberikan keyakinan memadai atas tercapainya tujuan organisasi melalui kegiatan yang efektif dan efisien, keandalan pelaporan keuangan, pengamanan aset negara, dan ketaatan terhadap peraturan perundang-undangan. Hal tersebut telah diamanatkan oleh Undang-Undang No 1 tahun 2004 yang menyatakan "Dalam rangka meningkatkan kinerja, transparansi dan akuntabilitas pengelolaan keuangan negara, Presiden selaku Kepala Pemerintah mengatur dan menyelenggarakan Sistem Pengendalian Intern di lingkungan pemerintah secara menyeluruh. SPI ditetapkan dengan Peraturan Pemerintah. Untuk melaksanakan hal tersebut pada tahun 2008 telah terbit PP No 60 tentang Sistem Pengedalian Intern Pemerintah

2. Komitmen dari pimpinan

Dukungan yang kuat dari pimpinan merupakan kunci keberhasilan dari suatu perubahan. Salah satu penyebab kelemahan penyusunan Laporan Keuangan pada beberapa Kementerian atau Lembaga adalah lemahnya komitmen pimpinan satuan kerja khususnya SKPD penerima dana Dekonsentrasi/Tugas Pembantuan.

\section{Simpulan dan Saran}

\subsection{Simpulan}

Dapat disimpulkan bahwa penggunaan akuntansi berbasis akrual lebih baik digunakan. Pemerintah menyadari perlunya perubahan dari akuntansi berbasis kas menuju akuntansiberbasis akrual, karena pada saat ini kebanyakan perusahaan menggunakan basis akrual dan meninggalkan basis kas. Karena itu pemerintah membuat peraturan penggunaan akuntansi basis akrual pada pembuatan laporan keuangan sektor pemerintahan. Basis akrual juga memiliki beberapa kelebihan yang membuat hasil dari laporan keuangan menjadi lebih baik lagi. Khususnya di BUMDes penggunaan akuntansi berbasis akrual lebih baik digunakan daripada penggunaan akuntansi berbasis kas. Sejalan dengan UU 23 Tahun 2014 mengenai otonomi daerah maka terbitlah UU No 6 Tahun 2014 tentang desa sebagai muara dari asas desentralisasi itu sendiri yang didalamnya diatur tentang pengelolaan keuangan desa (Pasal 72). Dengan adanya UU tersebut maka desa berkewajiban untuk menyelenggarakan akuntansi untuk mendukung proses akuntanbilitas dan transparasi kepada publik. Dimana menurut ketua BUMDes Bapak Hendri Ari Susila bahwa pencatatan transaksi yang dilakukan di BUMDes Dwi Amertha Sari, Desa Jinengdalem sudah sesuai dengan peraturan yang berlaku. Dalam laporan keuangan yang dihasilkan setiap bulan maupun tahunnya sudah bisa dikatakan akurat dikarenakan transaksi yang setiap harinya terjadi dicatat dalam laporan buku harian.

\subsection{Saran}

1. Saran untuk BUMDes :

Diharapkan dari BUMDes Dwi Amertha Sari agar lebih memaksimalkan kinerja dalam pelayanan masyarakat dan lebih menerapkan pelatihan-pelatihan guna mengasah kemampuan masyarakat desa Jineng Dalem dalam hak pertanian, perdagangan, maupun kerajinan. Selain itu bagi pemerintah dan pengelola BUMDes Dwi Amertha Sari supaya segera lebih efektif dalam menjalankan unit-unit usaha lain dari BUMDes Dwi Amertha 
Sari dengan memberikan pelatihan kepada masyarakat agar tujuan dari BUMDes Dwi Amertha Sari lebih maksimal sehingga bisa memberikan kesejatraan bagi masyarakat yang merata, karena kebijakan seperti inilah yang lebih efektif iterapkan ditingkat desa, suatu lembaga usaha ekonomi yang berbadan hukum yang dikelola seluruhnya untuk masyarakat desa dan hasilnya untukmasyarakat itu sendiri.

2. Saran untuk Peneliti selanjutnya :

Diharapkan dari peneliti selanjutnya agar mencari data lebih lengkap, berkoordinasi terlebih dahulu kepada BUMDes atau tempat lain yang ingin diteliti, dan juga tidak terlalu berpacu pada satu tempat agar tidak memperlambat waktu proses pengerjaan penelitian selanjutnya, Dan untuk peneliti selanjutnya agar menentukan tempat yang akan diteliti dan pastikan apakah BUMDes ataupun tempat yang akan diteliti memiliki karyawan atau pegawai yang memadai karena dari pengalaman kami banyak tempat yang tidak bisa melayani karena minimnya pegawai atau petugas sehingga tidak sempat kami wawancarai. Selain itu usahakan sebelum melakukan penelitian agar menghubungi pegawai atau staf yang bertugas di tempat itu dengan kata lain membuat janji pertemuan, hal ini bertujuan agar kita bisa lebih mengefisienkan waktu karena banyak BUMDes yang kami mau teliti tidak bisa diwawancari alasannya karena belum memiliki janji dengan pegawai yang mau diwawancarai.

3. Saran bagi Masyarakat :

Diharapkan bagi masyarakat khususnya yang bertempat di Jineng Dalem untuk mendukung segala bentuk program yang telah diusulkan oleh BUMDes Dwi Amertha Sari dalam rangka membantu masyarakat Jineng Dalem dalam pelatihan dalam bidang pertanian, perdagangan, maupun kerajianan dan memberikan pengetahuan kepada masyarakat tentang program atau pelatihan yang diberikan oleh BUMDes dan dapat dimanfaatkan oleh masyarakat. Kami berharap agar masyarakat setempat bisa lebih bijak dalam memajukan desanya, yakni dengan cara terus mendukung dan berpartisipasi dalam kegiatan BUMDes Dwi Amertha Sari. Dan tentunya kami berharap agar masyarakat bisa memanfaatkan dan membantu mengelola BUMDes Dwi Amertha Sari agar tujuan dari peerintah dalam memajukan dan mensejatrakan masyarakatnya bisa tercapai dengan merata.

\section{Daftar Pustaka}

Sakaputra, Ariyaguna. 2018. Akuntansi Akrual : Penerapan Terhadap Tata Kelola Keuangan Desa. Diakses pada 14 Desember 2018, https://m.kumparan.com/ariyaguna-sakaputra/akuntansi-akrualpenerapannyaterhadap-tata-kelola-keuangan-desa

Kieso, Donald E.,Weygant, Jerry J., Warfield, Tery D.2010.Akuntansi Intermediate.Terjemah.Edisi Kesepuluh.Erlangga:Jakarta. Ikatan Akuntansi Indonesia.2010.Standar Akuntansi Indonesia.Salema Empat:Jakarta.

Guthrie, James, et al., (1990), The Public Sector: Contemporary Readings in Accounting and Auditing, Sydney, Harcourt Brace Jovanovich Publisher. Peraturan Pemerintah Nomor 71 Tahun 2010 tentang Standar Akuntansi Pemerintahan. 